\title{
Zonisamide is effective in the preventive therapy of chronic migraine
}

\author{
R Belvis ${ }^{*}$, A Aceituno, M Martinez-Corral \\ From The European Headache and Migraine Trust International Congress \\ London, UK. 20-23 September 2012
}

\section{Introduction}

Topiramate is the only approved oral preventive drug for chronic migraine (CM). However, we usually use other preventive drugs of prevention of frequent episodic migraine. Zonisamide is a neuromodulator that has showed efficacy in prevention of CM.

\section{Objectives}

To evaluate the efficacy of zonisamide after three months of therapy in CM patients (IHS-2006 criteria) that present inefficacy/intolerance/contraindication to topiramate, sodium valproate, â-blocks and flunarizine.

\section{Methods}

Doses ZNS: 50-200mg. Primary end-point: Number of migraine days-NMD: Ineffective response-Inef(reduction of days $<50 \%)$, good-G(50-75\%), excellent-Exc $>75 \%)$. Secondary end-points: number of migraine episodesNME; number of headache days-NHD; drug overuse; consumption of triptans and NSAIDs; EVA and MIDAS score, effective mean dose of ZNS, adverse events.

\section{Results}

We prospectively included 27 patients (May 2011-May 2012), $85.2 \%$ women. Twelve patients (44.4\%) presented 16 adverse events (100\% mild). Four of them-14.8\% left the therapy. NMD, in the 23 patients who finished the three months follow-up, was Exc-39.1\%, G-43.5\%, and Inef-17.4\%; NME was Exc-30.4\%, G-43.5\%, and Inef26.1\%; and NHD was Exc-34.8\%, G-39.1\%, and Inef-26.1\%. Drug overuse disappeared in $47.8 \%$ of overusers. The consumption of triptans and NSAIDs decreased 54.3\%, and 65.7\%. The EVA score decreased 3.7 points (56.2\%), and MIDAS scale score decreased 14.6 points (48.7\%). Effective mean doses of ZNS: $106.6 \mathrm{mg} /$ night.

\section{Conclusion}

Zonisamide presents a good profile of efficacy $(70.3 \%$ of responses) and an acceptable tolerance. It could be a useful therapeutic option in CM patients intolerants, refractory, or with contraindications for topiramate, and the other drugs preventive drugs of migraine.

Published: 21 February 2013

\section{References}

1. Pascual-Gómez J, Gracia-Naya M, Leira R, et al: Zonisamide in the preventive treatment of refractory migraine. Rev Neurol 2010, 50(3):129-132.

2. Mohammadianinejad SE, Abbasi V, Sajedi SA, Majdinasab N, Abdollahi F, Hajmanouchehri R, Faraji A: Zonisamide versus topiramate in migraine prophylaxis: a double-blind randomized clinical trial. Clin Neuropharmacol 2011, 34(4):174-177.

\section{doi:10.1186/1129-2377-14-S1-P215}

Cite this article as: Belvis et al:: Zonisamide is effective in the preventive therapy of chronic migraine. The Journal of Headache and Pain 2013 14(Suppl 1):P215.
Submit your manuscript to a SpringerOpen ${ }^{\circ}$ journal and benefit from:

- Convenient online submission

- Rigorous peer review

- Immediate publication on acceptance

- Open access: articles freely available online

- High visibility within the field

- Retaining the copyright to your article

Submit your next manuscript at $>$ springeropen.com 